\title{
CLINICAL ANALYSIS OF DESQUAMATIVE GINGIVITIS RELATED ORAL MUCOCUTANEOUS DISEASES
}

\begin{abstract}
Objectives: Several mucocutaneous diseases are responsible for desquamative gingivitis (DG) and diagnostic delays are common in these diseases due to non-specific clinical oral presentations. The present study aimed to analyze the clinical features of DG-related mucocutaneous diseases with oral manifestations and compare the findings with previous reports.
\end{abstract}

Materials and Methods: Thirty newly diagnosed patients with oral mucocutaneous disease in the Dermatology and Venereology Department of Akdeniz University Medical School, between January 2018 and January 2020, and referred to the Periodontology Department for periodontal treatment were evaluated retrospectively. Patients' demographic data (age and gender), medical comorbidities, primary lesion site (oral or skin), and clinical features of gingival and oral lesions (location and symptoms) were examined.

Results: There were 18 oral lichen planus (OLP), 8 pemphigus vulgaris (PV), and 4 mucous membrane pemphigoid (MMP) patients with oral involvements. The mean age of the patients was $50.03 \pm 9.71$ years with a female predominance (male to female ratio 1:1.7). All patients suffered from chronic burning sensation and oral pain. DG was detected in all three mucocutaneous diseases but OLP was the main disease associated with DG (60\%). However other oral mucosal lesions and extraoral involvements were more frequent in PV patients.

Conclusions: According to these results, OLP, MMP, and PV are the mucocutaneous diseases responsible for DG, and OLP is the most common cause of DG. Clinicians should be familiar with the clinical presentations and signs (patient complaints) of DG-related mucocutaneous disease for early diagnosis, proper treatment, and quality of life of the patient.

Keywords: Desquamative gingivitis, diagnosis, mucous membrane pemphigoid, oral lichen planus, pemphigus vulgaris.

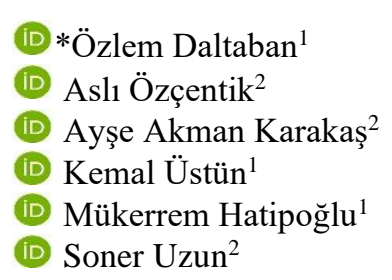

ORCID IDs of the authors:

Ö.D. 0000-0003-2246-8782

A.Ö. $\quad 0000-0003-2026-1120$

A.A.K. $\quad 0000-0002-5113-4178$

K.Ü. 0000-0001-9696-2041

M.H. 0000-0003-4698-292X

S.U. $\quad$ 0000-0001-7059-5474
Received : 12.08 .2020

Accepted : 06.10 .2020

How to Cite: Daltaban Ö, Özçentik A, Akman Karakaş A, Üstün K, Hatipoğlu M, Uzun S. Clinical Analysis of Desquamative Gingivitis Related Oral Mucocutaneous How to Cite: Daltaban O, Ozçentik A, Akman Kar
Diseases. Cumhuriyet Dent J 2020;23:4: 325-330.

*Corresponding Author:

Department of Periodontology, Faculty of Dentistry, Akdeniz University, Antalya, Turkey

Phone: +90 $3423606060 \quad$ Mobile Phone: $05326474557 \quad$ Fax: +90 $2423106967 \quad$ E-mail: daltabanozlem@yahoo.com 


\section{INTRUDUCTION}

Desquamative gingivitis (DG) is a clinical term to describe the presence of areas of smooth erythema, desquamation, and erosion of the attacehed and marginal gingiva. ${ }^{1}$ Clinically, the involved gingival epithelium is very fragile, there is a loss of stippling, and the surface may desquamate easily in response to minor trauma. ${ }^{2}$

Several mucocutaneous diseases, such as oral lichen planus (OLP), mucous membrane pemphigoid (MMP), pemphigus vulgaris (PV), lupus erythematosus, graft versus host disease, erythema multiforme, epidermolysis bullosa acquisita, chronic ulcerative stomatitis, dermatitis herpatiformis and linear IgA disease, may possess DG. ${ }^{1-3}$

Adequate knowledge of disease associated with DG is mandatory in daily clinical practice because the oral cavity can be the only site of involvement or as the first manifestation of the disease. ${ }^{3}$

A careful medical history and intraoral examination for erythematous gingiva and other oral lesions with specific appearances are extremely important in establishing a clinical diagnosis. ${ }^{2,4}$ However, DG-related mucocutaneous diseases frequently share similar clinical manifestations, so, further diagnostic methods, based on biopsy for histopathologic and direct immunofluorescence analysis (DIF), are considered to be the gold standard in diagnosis. . $^{1,5,6}$

Previous studies demonstrated that patients with oral mucosal diseases are widely misdiagnosed, leading to multiple consultations and insufficient treatments. ${ }^{7,8}$ Delays in the diagnosis and treatment of DG-related mucocutaneous disease may adversely affect the disease course, treatment response, and prognosis. ${ }^{9}$ Besides painful erosive or ulcerative gingival and oral lesions can significantly limits the patient's normal oral functions and interpersonal relationships. ${ }^{10}$

A lack of knowledge of primary health care practitioners for clinical features of oral mucosal diseases has been well documented in the literature. ${ }^{11-13}$ Therefore, this study aimed to examine the clinical features of patients with DGrelated mucocutaneous diseases, and compare the findings with previous reports.

\section{MATERIALS AND METHODS \\ Study Design}

This study protocol was approved by the Ethics Committee of the Medical Faculty of Akdeniz University Antalya, Turkey according to the Helsinki declaration (70904504\332-13.05.2020).

The present study is based on a retrospective review of patients with oral mucosa lesions who were newly diagnosed with DG-related mucocutaneous disease at the department of Dermatology and Venereology and were referred to the Periodontology department for periodontal treatment from January 2018 to January 2020. Patients who had non-specific histopathology and/or DIF or had previously been managed with systemic immunosuppressive agents were excluded. Diagnosis of DG-related mucocutaneous disease was established in all cases by clinical, histologic, and immunologic criteria described previously. ${ }^{14,15}$

Demographic data including age, gender, medical comorbidities, along with the primary site of lesions (oral or skin) and clinical presentations of the gingival and oral lesions were retrieved from patient records previously drafted for this study. The oral presentations for each disease were recorded according to the type of lesion (DG, nongingival erosions and/ ulcers) and involved sites. Symptoms in oral lesions were defined as pain or burning/itching sensation. The involvement of skin and/or other mucosal membranes was also documented.

\section{Statistical analysis}

Descriptive statistics for frequencies and percentages were calculated. The results were expressed as the mean \pm standard deviation and range. Mann Whitney U test was used to detect any significant differences between groups for age. All calculations were undertaken using a statistical software package SPSS (version 23 Chicago, IL, USA). A p value $<0.05$ was considered statistically significant.

\section{RESULTS}

A total of 40 patients have been initially selected, but 10 were excluded because these patients were 
on follow-up. Thirty patients fulfilled the inclusion criteria: 18 had OLP (60\%), 8 had PV (27\%), and
4 MMP (13\%). Demographic data and clinical presentations of patients are detailed in Table 1 .

Table 1: Demographic Data and Clinical Presentations of Patients

\begin{tabular}{llll}
\hline Clinical Features & OLP $(\mathrm{n}=18)$ & $\mathrm{PV}(\mathrm{n}=8)$ & $\mathrm{MMP}(\mathrm{n}=4)$ \\
\hline$\%$ for total & $60 \%$ & $27 \%$ & $13 \%$ \\
Mean age at onset & $51.17 \pm 10.97$ & $47.01 \pm 8.60$ & $51.00 \pm 4.76$ \\
Gender & & & 410 \\
Female to male ratio & $10 \backslash 8$ & 513 & \\
Oral Lesion Location (\%) & & & $100 \%$ \\
Desquamative gingivitis & $83 \%$ & $25 \%$ & $25 \%$ \\
Non-gingival erosions and ulcerations & & & $0 \%$ \\
Buccal mucosa & $44 \%$ & $88 \%$ & $25 \%$ \\
Labial mucosa & $0 \%$ & $50 \%$ & $0 \%$ \\
Palate & $0 \%$ & $50 \%$ & $0 \%$ \\
Tongue & $22 \%$ & $63 \%$ & $5 \%$ \\
Floor of the mouth & $0 \%$ & $13 \%$ & $50 \%$ \\
Extra-oral involvement (\%) & & & $0 \%$ \\
Pharynx & $0 \%$ & $63 \%$ & $0 \%$ \\
Larynx & $0 \%$ & $38 \%$ & $0 \%$ \\
Nasal mucosa & $0 \%$ & $13 \%$ & $25 \%$ \\
Conjunctiva & $0 \%$ & $13 \%$ & $0 \%$ \\
Vaginal & $6 \%$ & $25 \%$ & \\
Skin & $0 \%$ & $75 \%$ & \\
\hline OLP: Oral lichen planus, PV: Pemphigus vulgaris, MMP: Mucous membrane pemphigoid & & \\
\end{tabular}

OLP: Oral lichen planus, PV: Pemphigus vulgaris, MMP: Mucous membrane pemphigoid

The mean age of the patients was $50.03 \pm 9.71$ years, varying from 32 to 68 years $(48.54 \pm 10.20$ for males and $51.11 \pm 11.26$ for females) with a female predominance (male to female ratio 1:1.7). The medical comorbidities of the patients included essential hypertension (4 patients), diabetes mellitus (2 patients), and hypothyroidism (2 patients).

There were 18 OLP patients: 10 female and 8 male patients. The mean age at diagnosis was 51.17 \pm 10.97 years. The gingiva was the most affected site of involvement (83\%), followed by the buccal mucosa (44\%), and tongue (22\%). The erosive gingival lesions involved attached and marginal gingiva with 8 of them in a mixed form (erosive and reticular). DG was the sole manifestation in 10 cases (56\%). Only one female patient had extraoral involvement (genital mucosa).

There were $8 \mathrm{PV}$ patients with oral mucosal involvement, comprising 5 (63\%) females and 3 males $(37 \%)$ with a female predominance. The mean age at the onset of the disease was $47.01 \pm$ 8.60 years $(45.67 \pm 13.5$ for males and $47.80 \pm 6.01$ for females). Two of $8 \mathrm{PV}$ patients $(25 \%)$ had oral mucosal lesions only. In 6 patients $(75 \%)$, the disease initially began as persistent oral mucosal lesions, and then extended to involve the skin. All patients had erosive and/or ulcerative oral lesions. In the intraoral examination, the most affected anatomical site was the buccal mucosa (88\%), followed by the tongue (63\%), palate (50\%), lips $(50 \%)$, gingiva $(25 \%)$ and floor of the mouth (13\%). The involvement of other mucosal lesions was also observed as the pharynx (63\%) larynx (38\%), nasal mucosa (13\%), vaginal (25\%), and conjunctiva (13\%) as well as skin and/or oral mucosa involvements.

There were 4 MMP patients. All of them were female and the mean age at diagnosis was $51.00 \pm$ 4.76 years. DG was evident in all MMP cases and was the sole manifestation in $50 \%$ cases. Oral mucosa lesions were buccal mucosa $(25 \%)$ and palate $(50 \%)$. Pharynx was involved in two patients and vaginal mucosa in one patient. None of the patients developed cutaneous and ocular lesions. The clinical characters of gingival lesions were diffuse erythematous lesions with ulcers and erosions on the attached gingiva.

\section{Symptoms}

All patients complained of mild or moderate oral discomfort, and reported chronic soreness and burning sensation (93\% $\mathrm{n}=28)$ particularly when 
eating acidic foods, and pain $(60 \% \mathrm{n}=18)$ with oral function. One MMP patient had sore throat. In PV patients, the persistent painful ulcerations of the pharynx and larynx produced dysphagia $(n=5$, $63 \%)$, and odynophagia $(n=2,25 \%)$.

\section{DISCUSSION}

The analysis of this report revealed that OLP, MMP, and PV are responsible for DG. A common feature seen in all three diseases is that females are more frequently affected than males. Another common characteristic is that OLP, MMP and PV are diseases of older ages. There were no notable differences in the age distribution of patients with different diseases $(p>0.05)$. Similar observations have been reported by other investigators. ${ }^{16,17}$

OLP is a common chronic immunologically cell-mediated mucocutaneous disease in which host $\mathrm{T}$ lymphocytes play a key role in the development of the lesions. ${ }^{3,18}$ In the present study, OLP was the primary disease associated with DG (60\%). This observation is in accordance with most previous reports. ${ }^{2,16}$ Further analysis of our clinical data showed that the majority of OLP lesions in the gingivae are of the erosive or ulcerative form with 8 of them in a mixed form (erosive and reticular). Mignogna et al. ${ }^{19}$ presented a large series of patients with gingival OLP and found that the mixed forms were the most frequent.

$\mathrm{PV}$, is a potentially life-threatening, rare, autoimmune mucocutaneous disease whose early diagnosis in the oral cavity and timely referral may significantly change the course and progression of the disease. ${ }^{1,20}$ The pathogenesis of the disease is characterized by acantholysis and intraepithelial blister formation, resulting from $\mathrm{IgG}$ autoantibodies directed against desmosomal intercellular adhesion molecules (desmogleins) present on keratinocytes, mainly desmoglein $3 .^{2,6}$ In this study, oral involvement is the first sign of $\mathrm{PV}$, and skin lesions manifest in $75 \%$ of our patients. All of our patients with PV have painful, hemorrhagic irregular, long-persisting multiple erosions, and ulcers on the oral mucosa. Compared to MMP and OLP patients, DG was evident in $25 \%$ of our PV patients, but other oral mucosa involvements were more frequent, and the most common site of disease presentation was the buccal mucosa (88\%). This result confirms the findings of Leao et al. ${ }^{16}$ that PV account for the minority of DG lesions. Mignogna et $a l^{21}$ also reported a retrospective study of all cases of oral PV revealing gingival involvement in 8 of eighteen patients (44\%) with DG representing the sole oral presentation in 2 of eighteen patients (11\%).

MMP, is a subepithelial blistering autoimmune disease that predominantly manifests in the oral cavity. ${ }^{4,5}$ The pathogenesis of the disease is characterized by autoantibodies, predominantly, $\mathrm{IgG}$ with complement factor $\mathrm{C} 3$, directed against epithelial basement membrane adhesion proteins, BP180, BP230 and laminin 332. ${ }^{6,22}$ In this study, all MMP patients had DG and it was the sole manifestation in 50\% cases. In a cohort of $26 \mathrm{MMP}$ patients and $31 \mathrm{PV}$ patients with oral presentations, Sultan et al. ${ }^{23}$ showed that gingival lesions were significantly more common in MMP patients (84\%) as compared to PV patients (28\%).

All of the patients in the present study suffered from chronic burning sensation and oral pain. However, patients with PV have a more severe disease progression, and pain was the main complaint with dysphagia (63\%), and odynophagia $(25 \%)$. These symptoms may have additional information for clinicians when diagnostic possibilities are being considered in a patient with erosive and or ulcerative oral lesions.

DG can be easily misdiagnosed for plaqueinduced gingivitis, but specific clinical appearances of oral and gingival lesions may help to narrow the diagnosis, such as small blisters/vesicles, which have a relatively thick roof than PV and may be blood-filled in $\mathrm{MMP}^{3,22}$, and the presence of white plaques or striae at the periphery of the erosive lesions in OLP.,18 Additionally, Nikolsky's sign should be an integral part of the oral mucosal examination. ${ }^{24}$ However, a definitive diagnosis may be possible only with microscopic examination. . $^{24-6}$

Once a definitive diagnosis of the cause of DG has been established, special multidisciplinary coordinated approaches should be taken because; MMP can affect conjunctiva which may result in subconjunctival scarring (symblepharon) and 
eventually permanent blindness ${ }^{22,25}, \mathrm{PV}$ is a serious mucocutaneous disease which can be fatal if untreated, ${ }^{20,26}$ and OLP has a risk for malignant transformation. ${ }^{18}$

The main limitation of this study was the limited sample size and relatively short observation period. But performing this type of study is very important as the studied diseases are rare and often difficult to diagnose in their initial stages. Further multicenter, long-term prospective studies with larger patient groups will probably give more valuable information.

\section{CONCLUSIONS}

Within the limits of the present study, it is concluded that OLP, MMP and PV are the mucocutaneous diseases associated with DG. As the initial presentations of these diseases frequently occur in the oral cavity, general practitioners (medical and dental) should become familiar with the clinical presentations of DG-related mucocutaneous diseases, for providing proper management of these conditions.

\section{CONFLICT OF INTEREST}

The authors declare that they have no conflict of interest.

\section{Deskuamatif Gingivitis ile İlişkili Oral Mukokutanöz Hastalıkların Klinik Analizi}

\section{$\ddot{O} Z$}

Amaç: Birçok mukokutanöz hastalık, deskuamatif gingivitis lezyonlarından (DG) sorumludur ve bu hastalıklarda, spesifik olmayan ăgız bulguları nedeniyle, tanisal gecikmeler oldukça yaygındır. Bu çalışmada DG ile ilişkili mukokutanöz hastalıkların klinik özelliklerinin incelenmesi ve bulguların daha önceki çalşmalarla karşılaştırılması amaçlanmıştır. Gereçler ve Yöntem: Ocak 2018 ve Ocak 2020 tarihleri arası Akdeniz Üniversitesi Dermatoloji bölümünde DG ile ilişkili mukokutanöz hastalı tanısı alan ve periodontal tedavi amacıla Periodontoloji bölümüne yönlendirilen 30 yeni teşhis hastası retrospektif olarak değerlendirildi. Hastaların demografik verileri (yaş ve cinsiyet), sistemik hastalıklarl, ilk lezyon bölgesi (oral veya deri) ve dişeti ve oral mukoza lezyonlarının klinik özellikleri (lokalizasyon ve semptomlarl) değerlendirildi. Bulgular: Oral tutulumu olan 18 oral liken planus $(O L P), 8$ pemfigus vulgaris $(P V)$ ve 4 mukoz membran pemfigoid (MMP) hastasl vardl. Hastaların yaş ortalaması $50.03 \pm 9.71$ ve kadın oranı daha yüksekti (erkek/kadın oranı 1: 1.7). Tüm hastalarda ăgız içerisinde kronik yanma hissi ve ăgrı şikâyeti vardı. Her üç mukokutanöz hastalıkta da DG bulgusuna rastland ancak OLP, DG bulgusuna en sık rastlanan mukokutanöz hastalıtı (\%60). PV hastalarında ise diğer oral mukozal lezyonlar ve ekstraoral tutulumlara daha sik rastlandı. Sonuçlar: Bu sonuçlara göre, OLP, MMP ve $P V$ deskuamatif gingivitisten sorumlu mukokutanöz hastalıklardır ve OLP, deskuamatif gingivitisin en yaygın nedenidir. Klinisyenler, erken teşhis, uygun tedavi ve hastaların yaşam kalitesinin arttırılması açısından DG ile ilişkili mukokutanöz hastalıkların klinik özellikleri ve belirtilerine karşı daha fazla bilgi sahibi olmalıdır.

\section{REFERENCES}

1. Maderal AD, Lee Salisbury P, 3rd, Jorizzo JL. Desquamative gingivitis: Diagnosis and treatment. J Am Acad Dermatol 2018;78:851-861.

2. Lo Russo L, Fedele S, Guiglia R, et al. Diagnostic pathways and clinical significance of desquamative gingivitis. J Periodontol 2008;79:4-24.

3. Rashid H, Lamberts A, Diercks GFH, et al. Oral Lesions in Autoimmune Bullous Diseases: An Overview of Clinical Characteristics and Diagnostic Algorithm. Am J Clin Dermatol 2019; 20:847-861

4. Leuci S, Ruoppo E, Adamo D, Calabria E, Mignogna MD. Oral autoimmune vesicobullous diseases: Classification, clinical presentations, molecular mechanisms, diagnostic algorithms, and management. Periodontology 2000 2019;80:77-88.

5. Sciubba JJ. Autoimmune oral mucosal diseases: clinical, etiologic, diagnostic, and treatment considerations. Dent Clin North Am 2011;55:89-103.

6. Suresh L, Neiders ME. Definitive and differential diagnosis of desquamative gingivitis through direct immunofluorescence studies. J Periodontol 2012;83:1270-1278.

7. Hassona Y, Cirillo N. Diagnostic patterns and delays in autoimmune blistering diseases of the mouth: A cross-sectional study. Oral Dis 2018;24:802-808.

8. Sirois DA, Fatahzadeh M, Roth R, Ettlin D. Diagnostic patterns and delays in pemphigus vulgaris: 
experience with 99 patients. Arch Dermatol 2000;136:1569-1570.

9. Saha M, Bhogal B, Black MM, Cooper D, Vaughan RW, Groves RW. Prognostic factors in pemphigus vulgaris and pemphigus foliaceus. $\mathrm{Br} \mathrm{J}$ Dermatol 2014;170:116-122.

10. Ghodsi SZ, Chams-Davatchi C, Daneshpazhooh M, Valikhani M, Esmaili N. Quality of life and psychological status of patients with pemphigus vulgaris using Dermatology Life Quality Index and General Health Questionnaires. J Dermatol 2012;39:141-144.

11. Gomez I, Warnakulasuriya S, Varela-Centelles PI, et al. Is early diagnosis of oral cancer a feasible objective? Who is to blame for diagnostic delay? Oral Dis 2010;16:333-342.

12. Ergun S, Ozel S, Koray M, Kurklu E, Ak G, Tanyeri H. Dentists' knowledge and opinions about oral mucosal lesions. Int J Oral Maxillofacial Surg 2009;38:12831288 .

13. Scott SE, Grunfeld EA, Main J, McGurk M. Patient delay in oral cancer: a qualitative study of patients' experiences. Psychooncology 2006;15:474-485.

14. Scully C, Porter SR. The clinical spectrum of desquamative gingivitis. Seminars in cutaneous medicine and surgery 1997;16:308-313.

15. Murrell DF, Dick S, Ahmed AR, et al. Consensus statement on definitions of disease, end points, and therapeutic response for pemphigus. J Am Acad Dermatol 2008;58:1043-1046.

16. Leao JC, Ingafou M, Khan A, Scully C, Porter S. Desquamative gingivitis: retrospective analysis of disease associations of a large cohort. Oral Dis 2008;14:556-560.
17. Lo Russo L, Fierro G, Guiglia R, et al. Epidemiology of desquamative gingivitis: evaluation of 125 patients and review of the literature. Int $\mathrm{J}$ Dermatol 2009;48:1049-1052.

18. Alrashdan MS, Cirillo N, McCullough M. Oral lichen planus: a literature review and update. Arch Dermatol Res 2016;308:539-551.

19. Mignogna MD, Lo Russo L, Fedele S. Gingival involvement of oral lichen planus in a series of 700 patients. J Clin Periodontol 2005;32:1029-1033.

20. Black M, Mignogna MD, Scully C. Number II. Pemphigus vulgaris. Oral Dis 2005;11:119-130.

21. Mignogna MD, Lo Muzio L, Bucci E. Clinical features of gingival pemphigus vulgaris. J Clin Periodontol 2001;28:489-493.

22. Bagan J, Lo Muzio L, Scully C. Mucosal disease series. Number III. Mucous membrane pemphigoid. Oral Dis 2005;11:197-218.

23. Sultan AS, Villa A, Saavedra AP, Treister NS, Woo SB. Oral mucous membrane pemphigoid and pemphigus vulgaris-a retrospective two-center cohort study. Oral Dis 2017;23:498-504.

24. Mignogna MD, Fortuna G, Leuci S, Ruoppo E, Marasca F, Matarasso S. Nikolsky's sign on the gingival mucosa: a clinical tool for oral health practitioners. J Periodontol 2008;79:2241-2246.

25. Bystryn JC, Rudolph JL. Pemphigus. Lancet (London, England) 2005;366:61-73.

26. Endo H, Rees TD, Hallmon WW, et al. Disease progression from mucosal to mucocutaneous involvement in a patient with desquamative gingivitis associated with pemphigus vulgaris. J Periodontol 2008;79:369-375. 